\title{
Pengembangan Metode Bandongan dalam Kajian Kitab Kuning di Pesantren Attarbiyah Guluk-Guluk dalam Perspektif Muhammad Abid al-Jabiri
}

\author{
Effendi Chairi \\ Mahasiswa Program Pascasarjana Fakultas Ushuluddin dan Pemikiran Islam \\ UIN Sunan Kalijaga Yogyakarta \\ Email: effendichairi@gmail.com
}

\begin{abstract}
Abstrak
Tulisan ini mendiskusikan satu langkah pengembangan metode bandongan yang diterapkan di Pesantren Attarbiyah di Madura. Fenomena perkembangan ini, penulis analisis dengan menggunakan pendekatan filosofis-kontemporer untuk mengetahui dasar-dasar metodologisnya dalam melakukan pengembangan dan keberhasilannya. Dalam hal ini, penulis menggunakan pemikiran Abid al-Jabiri tentang turats sebagai pedoman utama dalam melakukan pengamatan. Namun penulis juga menggunakan pendekatan lain untuk menganalisis bagian-bagian penting yang sedang dikembangkan, seperti pemikiran Paulo Friere yang digunakan untuk memdedah metode bandongan dan Taksonomi Bloom untuk menganalisis keberhasilah pengembangan metode ini.

Tulisan ini mengemukakan hasil analisis yang menarik, bahwa perkembangan metode bandongan di pesantren Attarbiyah dapat dikatakan berhasil karena beberapa hal. Pertama adalah kesinambungan tradisi dan kemodernan dan hal ini sinkron dengan pemikirannya Abid al-Jabiri maupun kaidah ushul-fiqh-al-mubafadzatu 'ala qadim alshalih, wa al-abdzu bi al-jadid al-ashlah. Kedua, terdapat sesi diskusi di antara santri yang sebelumnya tidak pernah terjadi karena sistemnya yang monolog, teacher-centred, dan indoktrinatif. Di sisi lain dapat juga dikatakan gagal, walaupun tidak sepenuhnya, karena pemahaman santri bukan hasil kemandirian berpikir mereka yang kritis. Akan tetapi hasil konstruksi kiai.
\end{abstract}

Kata kunci: Pesantren, Bandongan, Turats.

\begin{abstract}
This article discusses one of development step of bandongan method applied at Pesantren Attarbiyah in Madura. In actual fact, author analyzed it by using contemporary of philosophical approach to find out the methodological basis in carrying out development and to fine out its success. In this case, author used Abid al-Jabiri's thought of turats as a main approach in making observations. But author also used other approaches to analyze other main object within it, such as Paulo Friere's thought used to analyze bandongan method and taxonomy's Bloom used to analyze the success of it.
\end{abstract}

Nidhomul Haq: Jurnal Manajemen Pendidikan Islam

ISSN: 2503-1481 Hal: 70-89

DOI: $10.31538 /$ ndh.v4i1.233 
This article presents the interesting research result that the development of bandongan method at Pesantren Attarbiyah can be mentioned successful because of several reasons. The first is continuity between tradition and modernity and it is synchronic with Abid al-Jabiri's thought and the ushul-fiqh's principle-al-mubafadratu 'ala qadim al-shalih, wa al-ahdzu bi al-jadid al-ashlah. Secondly, there is discussion season between santri that formerly had never happened for this method is monologue, teachercentered, and indoctrination. On the other hand, this also can be mentioned a failure, although it is not entirely, because the understanding of santri is not the result of their critical thinking independence. But it is created by kiai.

Keyword: Pesantren, Bandongan, Turats.

\section{A. PENDAHULUAN}

\section{Bandongan merupakan salah satu} metode pengajaran tradisional yang digunakan untuk mengajarkan ilmu-ilmu agama dan juga ilmu pengetahuan lainnya. Disebut sebagai metode pengajaran tradisional karena sistemnya yang monolog, top-down, dan indoktrinatif. Hal ini dapat ditemukan dalam strategi-strategi pengajaran syari'at Islam di awal-awal penyebarannya, khususnya di Indonesia. Hampir di setiap desa dan beberapa di kota, pengajaran dasardasar syari'at Islam di ajarkan di surau dan di masjid (termasuk juga di langgar) dalam muatan yang lebih praktis, aktual dan sangat dibutuhkan oleh masyarakat untuk kebutuhan ritual sehari-seharinya sebagai penganut agama. ${ }^{1}$ Metode yang digunakan tidak lain adalah bandongan yang kemudian dipraktikkan dalam bentuk latihan-latihan,

1 Al Makin, Anti-Kesempurnaan: Membaca, Melibat dan Bertutur tentang Islam (Yogyakarta: Pustaka Pelajar, 2002), 18. seperti berwudlu', solat, dan lain sejenisnya. Penjelasan ini akan semakin menemukan relevansinya ketika melihat secara langsung penyebaran Islam pertama kali di tanah Jawa.

Dalam penejelasan ini, penulis tidak akan melihat dari mana datangnya Islam, tetapi akan dibuat lebih spesifik kepada strategi penyebarannya. Islam disebarkan oleh para pengembara yang berkelana ke banyak tempat dalam misi penyebaran Islam. Hampir semua pengembara itu adalah seorang sufi atau ahli tasawuf yang persuasif dan atraktif dalam menyebarkan Islam; menekankan penyesuaian dengan tradisi dan budaya setempat, ketimbang merubah praktik dan kepercayaan lokal secara total, dan menekankan ajaran yang substantif dari pada bentuk praktiknya. Mereka mengajarkan teosofi sinkretik yang dikembangkan dari dogma-dogma pokok Islam, sehingga pengembara tersebut mudah digemari oleh warga lokal, seperti 
penguasaan ilmu-ilmu magis, kepandaian mengobati, dan lain sejenisnya. Hal itu terjadi disebabkan karena keaktraktifannya dalam menyesuaikan ajaran-ajaran pokok Islam dengan tradisi, budaya dan kepercayaan lokal. Misi utama penyebarannya adalah perubahan keyakinan. Dengan demikian, berkat daya kharismatiknya sebagian guru sufi diperkenankan mengawini putri-putri bangsawan dan penduduk lokal. ${ }^{2}$

Seiring perkembangan pengajaran Islam, para penyebar agama ini memandang perlu untuk meningkatkan efisiensi pengajaran supaya ilmu agama dan juga ilmu pengetahuan lainnya bertambah dan meningkat, sehingga mereka membangun tempat sebagai fasilitas yang dapat mempermudah proses pengajaran. ${ }^{3}$ Inilah cikal-bakal dari pesantren. Metode bandongan menjadi metode yang terus digunakan di dalam pesantren walaupn muatannya lebih rumit dan kurang praktis dibandingkan dengan muatan yang di surau dan di masjid. Oleh karenanya, metode bandongan dapat disebut metode tradisional.

Namun demikian, tidak sedikit kalangan yang mengkritik keberlangsungan pesantren hari ini. Kritik tersebut

2 Azyumardi Azra, Jaringan Ulama Timur Tengah dan Kepulanan Nusantara Abad XVII \& XVIII; Akar Pembaruan Islam Indonesia (Jakarta: Kencana, 2005), 1415; Sayfa Aulia Achidsti, "Strategi Penyebaran Tradisi Islam pada Masyarakat Jawa," Ibda': Jurnal Kebudayaan Islam, 10, no. 2, (Juli-Desember, 2012): 206.

${ }^{3}$ Mohammad Takdir, Modernisasi Kurikulum Pesantren: Konsep dan Metode Antroposentris (Yogyakarta: Ircisod, 2018), 26-34. mengindikasi adanya stagnasi keilmuan di pesantren. Ada banyak faktor yang sebenarnya menyebabkan stagnasi tersebut, baik dulu maupun hari ini. Salah satu yang akan penulis kemukakan adalah lantaran kitab kuningnya yang klasik dan dikaji dengan menggunakan metode bandongan dan terkadang dengan metode sorogan. Sehingga yang terjadi adalah kebaradaan kitab kuning (apapun jenis kitabnya) seolah dipertahankan, bebas kritik, dan karenanya dianggap final. ${ }^{4}$ Walaupun demikian, hal itu sudah disadari betul oleh kalangan pesantren, sehingga kitab-kitab kuning (kutub al-turats) yang dipelajari saat ini tidak sedikit yang baru (kutub al-mua'sirab) dan kedudukannya dianggap tidak lebih dari sekedar produk budaya yang absah dikaji dengan metode-metode kontemporer. Salah satu metodenya adalah pengembangan dari metode bandongan.

Hal ini terjadi di dalam Pesantren Attarbiyah Guluk-Guluk, Sumenep-Madura (gambaran pokok mengenai Pesantren Attarbiyah dijelaskan pada bagian ketiga). Fenomena belakangan di Pesantren Attarbiyah menunjukkan perkembangan evolutif khususnya di dalam metode kajian kitab kuning. Pengembangannya disebut sawir (tanpa menghilangkan karakter

4 Mujamil Qomar, Pesantren: Dari Transformasi Metodologi Menuju Demokratisasi Insitusi (Jakarta: Erlangga, 2009), 128; Uci Sanusi, "Transfer Ilmu di Pesantren: Kajian Mengenai Sanad Ilmu," Ta'lim: Jurnal Pendidikan Agama Islam 11, no. 1 (2013): 64; Aisatun Nurhayati, "Literatur Keislaman dalam Konteks Pesantren,” Pustakaloka 5, no. 1 (2013): 120. 
bandongan-nya) yang pertama kali digunakan dalam mengkaji ilmu mahwu dan di perluas pada kajian kitab-kitab lainnya.

Tulisan ini akan mendiskusikan pengembangan metode bandongan (dalam studi kasus di Pesantren Attarbiyah) yang dianalisis menggunakan pendekatan turats Muhammad Abid al-Jabiri (ilmuan kontemporer Maroco) yang dipadu dengan teori-teori lainnya. Tujuannya adalah untuk mengetahui perkembangan keilmuan dan metode kajian kitab kuning di pesantren, dan bagaimana strateginya dalam melakukan pengembangan. Hasil dari penelitian ini adalah untuk memberikan sumbangan pemikiran dalam proyek pengembangan pesantren secara khsusus, dan kebangkitan tradisi Islam pada umumnya.

\section{B. KAJIAN TEORI}

Penelitian ini pada dasarnya adalah penelitian tentang tradisi, yaitu tradisi pengkajian kitab kuning di dalam tradisi pesantren yang sudah umum digunakan. Sebagaimana tujuan dari penelitian ini yang telah disampaikan di bagian awal, penggunaan kerang teori (teoritical framework) sangat diperlukan untuk membantu peneliti dalam mengamati dan membuat rumusan hasil penelitian. Kerangka teori utama dalam penelitian ini adalah paradigma turats yang dikonstruksi oleh Muhammad Abid al-Jabiri. Penentuan kerangka teori harus menyesuaikan dengan karakter dan watak objek kajian yang akan diteliti. ${ }^{5}$ Di sisi lain, kerangka teori yang digunakan di dalam sebuah agenda penelitian sebetulnya tidak untuk diterapkan begitusaja seperti bahanbahan masakan yang tertera dalam komposisi. Akan tetapi penggunaannya adalah untuk memandu langkah-langkah penelitian dan perumusan data hasil penelitian. ${ }^{6}$

Karakter dan watak pesantren akan diungkap terlebih dahulu untuk menunjukkan akurasi penggunaan paradigma turats Abid al-Jabiri dalam penelitian ini. Pesantren adalah lembaga pendidikan keagamaan yang memiliki sistem dan tatanan sosial yang khas. ${ }^{7}$ Pesantren memiliki dua bidang pekerjaan. Tidak hanya dalam bidang keagamaan semata, melainkan juga memiliki andil yang cukup besar dalam bidang sosial dan budaya. Peranannya dalam bidang sosial adalah sebagai agen perubahan sosial dan transformasi budaya tanpa meninggalkan kebudayaan lokal dan ajaran fundamental Islam (al-Quran dan sunnah), dan penyelesai persoalan kemasyarakatan (problem solving agent). ${ }^{8}$ Pesantren dalam mengupayakan sebuah pengembangan tidak

\footnotetext{
${ }^{5}$ Muhammad Abid al-Jabiri, Post-Tradisionalisme Islam (Yogyakarta: LKIS, 2000), 1.

${ }^{6}$ Geroge Ritzer, Sosiologi Ilmu Pengetahuan Berparadigma Ganda (Yogyakarta: Pustaka Pelajar, 2014), 86.

7 Hamdan Farchan dan Syarifuddin, Titik Tengkar Pesantren. Resolusi Konflik Masyarakat Pesantren (Yogyakarta: Pilar Media, 2005), 75.

8 Amin Haidari, dkk, Masa Depan Pesantren dalam Tantangan Modernitas dan Tantangan Kompleksitas Global (Jakarta: IRD Press, 2014), hlm. 12, 104-105.
} 
akan terlepas dari kaidah ushul-fiqh "almuhafadzatu 'ala qadim al-shalih, wa al-ahdzu bi al-jadid al-asblah" sebagai kerangka metodologisnya. Dalam kata lain, di dalam melakukan pembaruan tradisi atau sistem yang dijalankan, pesantren tidak pernah berangkat dari ruang kosong, akan tetapi tetap berpijak dan mempertahankan tradisitradisi atau sistem-sistem lama yang tentunya dianggap baik (menopang pembaruan). Pada saat yang sama, pesantren juga mengadopsi sistem-sistem baru yang bermanfaat dan mendukung proses pengembangan. ${ }^{9}$ Karakter dan watak ini memiliki logika yang sama dengan cara-cara Abid al-Jabiri dalam mengupayakan kebangkitan tradisi ArabIslam. Kondisi kekinian tidak akan terputus dari masa lalu, baik masa lalu itu bersumber dari tradisi sendiri (tradisi Timur) atau datang dari Barat, atau masa lalu yang dekat atau yang jauh dari kondisi kekinian. ${ }^{10}$

Tradisi tidak semata-mata sisa-sisa peninggalan masa lalu yang menyertai kondisi kekinian (kehadiran masa lalu ke masa kini), melainkan penyempurnaan terhadap kesinambungan dan ruang lingkup

9 Djohan Effendi, Pembaruan Tanpa Membongkar Tradisi: Wacana Keagamaan diKalangan Generasi Muda NU Masa Kepemimpinan GUS DUR (Jakarta: Kompas, 2010), 110.

${ }^{10}$ Muhammad Abid al-Jabiri, Post-Tradisionalisme..., 27, 24; Abdul Mukti Rouf, "Metode Pembcaan Turats Arab-Islam: Perspektif Muhammad Abid al-Jabiri," Ulumuna XIV, no. 1, (Juni 2010): 71; Muhammad Muslih, "Pemikiran Islam Kontemporer: Antara model Pemikiran dan Model Pembacaan," Jurnal Tsaqafah 8, no. 2, (Oktober 2012): 358; Siti A'isyah, "Membaca Al-Jabiri: Menggali Inspirasi dari PostTradisionalisme Islam," Jurnal Pusaka 2, no. 2, (Januari-Juni 2015): 21. kultur tersebut, yang di dalamnya terdapat bahasa, sastra, akal, agama, kerinduan dan harapan-harapan ke depan yang belum terwujud dan sangat mungkin untuk diwujudkan. Dengan demikian, tradisi menyimpan semangat kebangkitan (revivalism) yang harus bersandar pada tradisi masa lalu. Dengan kata lain, berpijak pada asas kebersamaan yang berakar dari tradisi dan kembali pada dasar-dasar ajaran untuk melakukan kritik (passing over) terhadap masa lalu dan masa kini. Kemudian melakukan lompatan-lompatan menuju masa depan yang lebih cerah. ${ }^{11}$

Karena pembacaan terhadap tradisi masa lalu dan masa kini menjadi kunci utama dalam upaya mengembangkan tradisi, metode bandongan yang dari awal lahirnya pesantren hingga hari ini masih digunakan harus dibaca ulang secara kritis. Dalam upaya melakukan pembacaan terhadap tradisi, Abid al-Jabiri menawarkan dua model pembacaan yang beruntun. Pertama dibutuhkan pembacaan secara objektif (maudlu'iyyah) terhadap metode bandongan; dan kedua perlu dibaca secara rasional (ma'quliyyah) agar dapat ditemukan kontribusinya pada kondisi hari ini dan ke depan. Akan tetapi dalam hal ini, Abid alJabiri tidak memberikan arahan dalam melakukan upaya ini. Di sisi lain, karena kesenjangan yang jauh antara tradisi ArabIslam yang dibaca Abid al-Jabiri dan tradisi

\footnotetext{
${ }^{11}$ Muhammad Abid al-Jabiri, Post-Tradisionalisme..., 8.
} 
pesantren, khususnya metode bandongan, peneliti mengadopsi teori lain yang membantu dalam melakukan pembacaan secara objektif dan rasional terhadap metode bandongan di pesantren.

\section{GAMBARAN POKOK PESANTREN ATTARBIYAH}

Pesantren At-Tarbiyah bertempat di Dusun Brakas Daja RT 001/RW 007. Yaitu suatu daerah di ujung barat Kecamatan Guluk-Guluk, Kabupaten Sumenep, Provinsi Jawa Timur. Munculnya pesantren ini sekitar pada tahun 1967. Pesantren ini bermula dari sebuah komplek pengajaran agama Islam di rumah Nurul Huda Basyir (selanjutnya akan penulis sebut Kiai Huda). Basyir merupakan ayahanda Kiai Huda yang sebelumnya telah mengajarkan masyarakat sekitar mempelajari Al-Quran dan ilmu-ilmu kecakapan beribadah. Dalam sejarahnya, masyarakat setempat meminta Kiai Huda untuk mengembangkannya karena jarak tempuh ke lembaga yang sudah tumbuh dan berkembang sangat jauh. Oleh karena hal tersebut, kemudian Kiai Huda beserta isterinya (Nyi Hamdiyah) mengembangkan pengajaran Islam, mulai dari sarana fisik berupa gedung sekolah, maupun muatan pengajarannya, yang mana pada tahap awal pengembangan Kiai Huda mengadopsi sistem pendidikan Madrasah Ibtidaiyah (MI) di bawah naungan Kementerian Agama. ${ }^{12}$

Layaknya roda kehidupan pada umumnya, Pesantren At-Tarbiyah mengalami perkembangan yang cukup pesat, khusunya sebelum tahun 1985 yang ditandai berdirinya Asrama atau pondok, sebagai penginapan santri, dan Masjid yang dibangun pada tahun 1980. Sejak berdirinya Asrama dan Masjid, kegiatan santri bertambah, yaitu program kajian kitab kuning yang diajarkan Kiai Huda kepada santri secara khusus, dan juga pada masyarakat.

Namun demikian, pada tahun 1985 menjadi awal masuknya pesantren ini pada masa kemundurannya hingga pada tahun 1991 awal. Pada masa kemunduran ini, hampir separuh santri satu persatu meninggalkan kamar pondoknya lantaran adanya pertemuan partai politik di lingkungan Pesantren. Akan tetapi Nyi Zulfa (salah satu puteri Kiai Huda) beserta para alumni yang mengabdikan dirinya pada pesantren berupaya keras mengembalikan kepercayaan masyarakat sekitar terhadap pihak pesantren yang sungguh-sungguh untuk membangun lembaga pendidikan yang fokus pada kecerdasan masyarakat. Semangat yang dibangun Nyi Zulfa beserta alumni pesantren tidak hanya untuk

12 Hasil wawancara kepada Moh. Judi, kepala MTs Attarbiyah, pada tanggal 11 November 2015, di kediamannya. 
mengembalikan kepercayaan masyarakat sekitar bahwa pesantren pada dasarnya tidak berpartisipasi dalam politik praktis pada masa itu, tetapi juga untuk mengembangkan pesantren. Sehingga pada tahun 1994 berhasil mendirikan Madrasan Diniyah (MD) dan Raudhatul Athfal (RA). Program pendidikan yang terkahir ini merupakan hasil gagasan alumni yang tekun dalam mengembangkan Pesantren Attarbiyah. Kemudian pada tahun 1996-an dengan masuknya Wakid Yusuf (salah satu menantu Kiai Huda yang menikahi salah satu puterinya yang bernama Nyi Maltufah) sebagai bagian dari keluarga pesantren mempengaruhi perkembangan pesantren hingga kembali jaya seperti semula dan terus berkembang hingga saat ini. Tidak hanya mengembalikan simpati atau kepatuhan masyarakat kepada sang guru, kualitas dan kuantitas pesantren-pun terus berkembang, mulai pembangunan gedung sekolah Madrasah Tsanawiyah pada tahun 2001 dan Madrasah Aliyah pada tahun 2003, serta pengembangan dan peningkatan programprogram dan kegiatan santri-santri, alumni dan masyarakat pada umumnya. ${ }^{13}$

Secara tipologi kepesantrenannya, Pesantren Attarbiyah dapat disebut sebagai pesantren modern atau pesatren khalaf. Mengapa demikian, gambaran sejarah singkat Pesantren At-Tarbiyah dari awal

${ }^{13}$ Hasil wawancara kepada Ust. Abu Syarah, alumni pertama Pesantren Attarbiyah, pada 20 November 2015, di kediamannya. pertumbuhannya hingga perkembangan terkahir ini secara teoritis dapat disebut sebagai pesantren yang tetap memepertahankan pengajaran kitab kuning dengan sistem sorogan dan bandongan sebagai metode utama. Akan tetapi pada saat yang sama, ia juga mengutamakan pengetahuan umum dengan bukti menerapkan pendidikan formal mulai dari jenjang Raudhatul Athfal (RA) hingga pada jenjang Madrasah Aliyah (MA) dan Madrasah Diniyah (MD).

Melihat gambaran di atas, Pesantren At-Tarbiyah dapat disebut sebagai pesantren modern atau khalaf, yaitu pesantren yang masih mengajarkan kitab kuning, dan juga membuka pendidikan formal secara bersamaan yang integratif. ${ }^{14}$

\section{MEMBACA ULANG METODE BANDONGAN SECARA OBJEKTIF DAN KRITIS}

Seperti yang telah ditentukan di awal, dalam upaya mengembangkan sebuah tradisi, masa lalu atau cara-cara lama tidak dapat dilepaskan dan ditinggalkan begitu saja. Dalam hal ini, pengembangan pesantren dapat meniru bangsa Arab (generasi Islam pertama) atau kebangkitan bangsa Eropa modern dalam membangkitkan tradisinya yang tidak meninggalkan masa lalunya demi

\footnotetext{
14 Ali Anwar, Pembaruan Pendidikan di Pesatren Lirboyo Kediri (Yogyakarta: Pustaka Pelajar, 2011), 26; Mujamil Qomar, Pesantren: Dari Transformasi..., 17.
} 
kebangkitannya, hal ini dijelaskan detail oleh Abid al-Jabiri. ${ }^{15}$ Akan tetapi masa lalu atau cara-cara lama harus dibaca secara kritis untuk menemukan relevansinya pada kondisi kekinian (mu'ashiran lana). Masa lalu yang perlu dibaca ulang dalam diskusi ini adalah metode bandongan dalam kajian kitab kuning di pesantren.

\section{Bandongan pertama-tama harus} dibaca secara objektif untuk mengetahui relevansinya dimasa-masa awal penyebaran Islam, atau lebih spesifik di awal-awal perkembangan pesantren. Namun sebelum membacanya secara objektif, metode bandongan perlu terlebih dahulu dijelaskan secara ringkas sebagai bahan review. Di dalam tradisi pesantren, minimal terdapat dua metode kajian kitab-kitab kuning (kutub al-qadim); sorogan dan bandongan. Praktik sorogan pada mulanya pernah dilakukan oleh Malik Ibnu Anas, seorang penggagas Mazhab Maliki atau yang lebih dikenal dengan sebutan Imam Malik, sewaktu mengajari para santri-santrinya. Nemun secara pasti menggunakan istilah tertentu yang dipakai untuk menyebutkan metode pembelajaran ini. Di Indonesia metode ini diperkenalkan oleh Kiai Idris (Tebuireng) kepada para santri-santrinya dalam kajian kitab kuning. ${ }^{16}$ Sorogan adalah sistem kajian

15 Muhammad Abid al-Jabiri, Post-Tradisionalisme..., 194-202.

16 Lihat Syamsul Ma'arif, dkk, "Inklusifitas Pesantren Tebuireng: Menatap Globalisasi dengan Wajah kitab kuning yang dilakukan oleh seorang santri dengan kiai. Dengan kata lain, santri menghadap kepada kiai dengan membawa satu kitab kuning yang akan dipelajarinya. Metode ini berjalan secara berhadaphadapan (vis a vis) antara seorang santri dan seorang kiai atau terkadang kepada orang yang ditunjuk oleh kiai (badal/asisten kiai). Namun demikian, di dalam metode sorogan, kiai pertama-pertama membaca dan menjelaskan kitab yang disodorkan (sorog) oleh santri. Setelah itu, santri membaca dan menjelaskan ulang apa yang telah disampaikan oleh kiai hingga santri tersebut memperoleh pengesahan dari kiai. Pengesahan tersebut adalah simbol bahwa santri tersebut memahami dan menguasai apa yang telah dibaca di dalam kitab yang dipelajarinya, baik itu al-Quran maupun kitab-kitab kuning. ${ }^{17}$

Adapun metode bandongan adalah berbeda dengan sorogan, walaupun ada kemiripan dalam beberapa hal. Bandongan (terkadang disebut wetonan) adalah metode kajian kitab kuning yang diikuti oleh banyak santri secara bersamaan. Santri duduk mengelilingi kiai yang sedang membaca kitab. Persamaannya dengan metode

Tradisionalisme," Jurnal Pembangunan Pendidikan: Fondasi dan Aplikasi 3, no. 1, (Juni, 2015): 91.

17 Hariadi, Evolusi Pesantren: Studi Kepemimpinan Kiai Berbasis Orientasi ESQ (Yogyakarta: LKIS, 2015), 80; Suprihatiningsih, Perspektif Manajemen Pembelajaran Program Keterampilan (Yogyakarta: Deepublish, 2016), 36; Zuhri, Convergentive Design Kurikulum Pendidikan Pesantren (Konsepsi dan Aplikasinya) (Yogyakarta: Deepublish, 2016), 195. 
sebelumnya, kiai menempati posisi dominan dan aktif. Dalam kata lain, kiai membaca, menterjemahkan, dan menjelaskan kandungan kitab kuning yang sedang dipelajari. Sedangkan santri menempati posisi pasif. Santri hanya mendengarkan dan mencatat apa yang dijelaskan oleh kiai. ${ }^{18}$ Dalam metode ini, salah satu santri yang mengikuti kajiannya terkadang diminta untuk membaca kitab yang sedang dipelajari, akan tetapi permintaan tersebut hanya terbatas pada pembacaan teks arabnya semata tanpa disertai penjelasan kandungannya. ${ }^{19}$ Jarang sekali, bahkan mungkin tidak pernah terjadi diskusi antara kiai dan santri, apalagi menghubungkan kandungan kitab kuning dengan problemproblem kontemporer yang dialami secara riil di masyarakat. Walaupun terkadang terdapat pertanyaan, umumnya pertanyaan tersebut hanya di batasi pada konteks sempit di dalamnya yang tidak jauh dari pembahasan kitabnya. ${ }^{20}$

Apa yang akan diperoleh ketika bandongan dibaca secara objektif, begitupula ketika dibaca secara rasionalkritis dengan bantuan pendekatan kontemporer? Pembacaan secara objektif

18 Sofyan Rofi, Sejarah Pendidikan Islam di Indonesia (Yogyakarta: Deepublish, 2018), 84; Kompri, Manajemen dan Kepemimpinan Pondok Pesantren (Jakarta: Kencana, 2018), 131.

19 Ali Usman, Kiai Mengaji, Santri Ajungkan Jari: Refleksi Kritis atas Tradisi dan Pemikiran Pesantren (Yogyakarta: Pustaka Pesantren, 2012), 41; Abdul Mughits, Kritik Nalar Figh Pesantren (Jakarta: Kencana, 2008), 151

20 Martin Van Bruinessen, Kitab Kuning, Pesantren, dan Tarekat (Yogyakarta: Gading Publishing, 2012), 87. sangat perlu dilakukan untuk menemukan relevansinya pada masa awal kemunculannya (mu'ashiran li-nafsibi/kontemporer bagi dirinya sendiri). Kebanyakan pesantren yang tumbuh di Indonesia, khususnya di tanah Jawa dan Madura, adalah pesantren yang bermula dari tradisi (salaf). Pesantren tersebut tidak lain merupakan pengembangan dari pengajaran dasar-dasar agama di pedesaan, baik itu dilakukan di masjid, langgar, atau bahkan rumah-rumah pribadi orang yang pandai ilmu-ilmu agama. Sehingga dalam pesantren model salaf ini, metode bandongan adalah metode pengajaran yang secara kuantitatif lebih efektif. Karena target utama yang paling pokok adalah penyelesaian pengajaran kitab kuning. Dalam melakukan pembacaan secara objektif terhadap metode ini, penulis akan menggunakan pendekatan taksonomi Bloom yang telah direvisi untuk menggambarkan dengan mudah langkah-langkah dan target yang akan dicapai dalam manajemen pendidikan. Walaupun B.S. Bloom (ilmuan ahli pendidikan Amerika) menghasilkan paradigmanya di luar konteks pesantren, akan tetapi seperti yang penulis singgung di atas bahwa suatu teori digunakan di dalam sebuah agenda penelitian semata-semata untuk menuntun langkah-langkan pengamatan dan penarikan kesimpulan. Di sisi lain, memperkaya atau diperkaya oleh tradisi lain merupakan hal positif dalam memburu ilmu pengetahuan. 
Taksonomi Bloom yang telah direvisi memiliki dua dimensi. Dua dimensi tersebut adalah dimensi pengetahuan dan dimensi kognitif. Dalam tulisan ini, penulis akan fokus pada dimensi kedua, dimensi kognitif yang fokus pada langkah-langkah pengajaran yang dapat mempermudah untuk mencapai tujuan pengajaran. Dalam dimensi kognitif, terdapat enam kategori yang berurutan, yaitu mengingat (remembering), memahami (understanding) mengamplikasikan (aplicating), menganalisis (analyzing), mengevaluasi (evaluating), dan mencipta (creating). ${ }^{21}$

Kategori pertama dalam dimensi kognitif, mengingat (remembering), mengupayakan suatu kemampuan peserta didik (santri atau siswa) untuk meretensi atau menyimpan cerita-cerita atau materi pelajaran yang telah disampaikan oleh kiai atau guru. ${ }^{22}$ Ketegori ini memiliki jalinan yang kuat dengan metode hafalan. Hafalan tidak lain adalah untuk mengingat. Di dalam banyak pesantren, metode hafalan hingga saat ini masih digunakan. Bahkan pada program tertentu, hafalan merupakan metode utama untuk dapat mengingat. Namun demikian, dalam hafalan tidak ada garansi bagi penghafal untuk memahami apa

21 Yulianti, "Pengembangan Alat Evaluasi Hasil Belajar Pelajaran Mata Pelajaran Pendidikan Agama Islam Berbasis Taksonomi Bloom Dua Dimensi," Joies 1, no. 2, (Desember 2016): 415.

22 Sri Fatmawati, "Perumusan Tujuan Pembelajaran dan Soal Kognitif Berorientasi pada Revisi Taksonomi Bloom dalam Pembelajaran Fisika," Edusain 1, no. 2 (Desember 2013) yang telah dihafal. Sebuah analisis yang sangat menarik dan bernada kritis, bahwa kebanyakan pesantren saat ini tidak mendorong santri untuk mempertanyakan tradisi dan kebudayaan Islam serta tidak melatih santri memiliki daya pikir yang kritis dan independen. Hal itu terjadi karena kebanyakan pesantren menekankan hafalan tanpa pemahaman kritis. ${ }^{23}$

Metode bandongan dalam analisis penulis masih berada pada level pertama dari Taksonomi Bloom ini. Hal itu disebabkan karena santri menduduki posisi pasif yang semata-mata menyimak apa yang disampaikan kiai, mencatat penjelasan kiai, dan kemudian menghafalnya. Hal ini relevan bagi tahap awal kemunculan pesantren, atau tahap awal penyebaran Islam. Sebagai salah satu contoh, pengajaran syari'at tidak akan terlepas dari pengajaran soal bersuci (Bab thabara), jenis-jenis air yang mensucikan dan lain sejenisnya, cara-cara berwudlu', melaksanakan solat, dan lain sejenisnya. Kiai atau penyebar syariat Islam akan mengajarkan hal itu tanpa pancapaian pemahaman yang kritis yang didapatkan oleh santri tentang wudlu' atau solat. Yang paling utama bagi kiai adalah mengajarkan tentang wudlu' hingga tuntas persoalan bab wudlu' dan santri bisa mempraktikannya, demikian juga tentang solat.

23 Charlene Tan. Islamic Education and Indoctrination; The Case in Indonesia (New York: Routledge, 2014), 120. 
Oleh karenanya, dalam analisis penulis metode bandongan sangat relevan bagi perkembangan awal pengajaran Islam dan ilmu-ilmu agama lainnya, begitu juga di dalam pesantren. Metode bandongan relevan digunakan karena tujuannya adalah mengindoktrinasi santri tentang dasar-dasar syari'at Islam, khususnya bagi santri-santri junior. Akan tetapi kesimpulan tentang metode bandongan ini akan berbeda ketika dilakukan pembacaan secara rasional-kritis (ma'quliyyah) untuk menemukan relevansinya terhadap kondisi kekinian (mu'ashiran lana).

Metode bandongan sebagaimana telah dijelaskan rinci di atas, dan relevan digunakan di dalam kompleks pesantren khususnya untuk menghafal, baik al-Quran, hadits, maupun ilmu pengetahuan lainnya. Sepintas tidak ada problem dari apa yang telah dijelaskan di atas. Akan tetapi pada kemampuan santri dalam memahami kandungannya hingga saat ini belum bisa dijamin. Karena pada praktiknya, kiai yang mendomminasi pembacaan kitabnya. Sedangkan santri tidak menjadi aktor yang aktif. Yang terjadi hanyalah pembelajaran yang monoton, dan teacher-centred. ${ }^{24}$ Dalam melakukan pembacaan secara rasionaliskritis, penulis akan menggunakan pendekatan Paulo Friere (teoretikus pendidikan asal Brazil) tentang pendidikan gaya bank dan tawaran-tawaran pengembangannya.

${ }^{24}$ Ali Usman, Kiai Mengaji..., 41.
Pendidikan gaya bank menjalin hubungan monologis dan top-down. Di dalamnya terdapat aktor yang aktif berbicara, bercerita, dan menjelaskan (yang disebut kiai atau guru) dan aktor kedua yang patuh mendengarkan dan mengingat apa-apa yang diceritakan (yang disebut santri atau murid). Kiai menjelaskan tentang realitas seolah-olah sebuah hal yang statis, baku, dan telah final. Sedangkan santri menyimak, mencatat, menghafal, dan mengulangi penjelasan-penjelasan sang guru walaupun tidak memahami arti sesungguhnya dari penjelasannya. Lebih dari pada itu, muridmurid tak ubahnya seperti bejana atau wadah kosong yang siap untuk diisi penuh oleh guru. Hukum yang berlaku adalah semakin penuh guru mengisi wadah itu, semakin baik pula sebagai seorang guru. Semakin patuh bejana itu untuk diisi, semakin baik pula mereka sebagai murid. Inilah pendidikan gaya bank yang ditolak oleh Freire, dimana ruang komunikasi yang tersedia hanya terbatas pada menerima, mencatat, dan menyimpannya. ${ }^{25}$

Demikian dalam metode bandongan, terdapat hukum yang sama dengan pendidikan gaya bank. Metode bandongan tidak menuntut santri untuk menunjukkan apa yang telah dipahami dari apa yang telah diterangkan dan dijelaskan oleh kiai. Target utama kiai adalah menyelesaikan pembacaan,

25 Paulo Freire, Pendidikan Kaum Tertindas Jakarta: LP3ES, 2011), 51, 52. 
penerjemahan, dan penjelasan kitabnya. ${ }^{26}$

Semakin banyak kitab yang telah dipelajari, maka semakin meningkat kuantitas pesantren tersebut. Begitupula santri, semakin banyak catatan dan hafalannya, maka semakin baik dalam menampung dan mencatat. Metode ini jika berhenti pada cara-cara lama yang monolog maka tidak relevan dengan perkembangan terkini. Dalam kata lain, pesantren dituntut untuk mengembangkan metode ini tanpa memutuskan mata-rantai tradisi dan kemodernannya.

Muncul pertanyaan baru, bagaimana mengembangkan metode bandongan yang sudah ditemukan krisisnya pada kondisi kekinian tanpa memutus jalin-kelindan antara tradisi dan kemodernan? Apa yang menuntut pengembangan metode ini, dan bagaimana pesantren dapat melakukannya? Penulis akan memulai merumuskan jawaban untuk pertanyaan-pertanyaan ini dari pertanyaan terakhir. Abid al-Jabiri pada dasarnya memberikan kritik pada kelompok tradisionalis (salafiyyun) yang secara sengaja mempertahankan cara-cara lama tanpa sedikit melakukan pengembangan untuk menemukan relevansi pada perkembangan peradaban. Yang dilakukan kolompok tradisionalis justru menjadikan sejarah kejayaan peradaban Islam-Arab periode pertama sebagai acuan dalam menjawab

26 Charlene Tan. Islamic Education and Indoctrination..., 119. tantangan-tantangan kekinian. ${ }^{27}$ Kesadaran kelompok tradisionalis akan menunjukkan taringnya ketika mengembang menjadi sebuah ideologi, yaitu sekumpulan idealideal etik, doktrin-doktrin aliran, dan ambisi sosial-politik. $^{28}$ Pada perkembangan ini, tradisionalisme mengembang menjadi fundamentalisme yang memproyeksikan kejayaaan masa lalu akan diulangi kembali pada masa sekarang dan ke depan. ${ }^{29}$ Abid alJabiri juga mengkritik kelompok modernis (badatsiyyun). Kolompok ini menjadikan modernitas Barat sebagai acuan dalam perdaban modern. Dalam kata lain, tradisi dipaksa tunduk dan patuh pada acuan tadi, yang jelas tidak memiliki akar kesinambungan dengan tradisi. ${ }^{30}$ Pendek kata, pembaruan atau pengembangan tidak bisa dilakukan dengan cara-cara konservatif, tetapi tidak bisa juga diupayakan dengan memutus tali kesinambungan dengan akar tradisi.

Sebagai gantinya, Abid al-Jabiri mengharmonisasikan kedua model di atas, yaitu munculnya kelompok ketiga sebagai sebuah antitesis. Kelompok ini mengupayakan sebuah pembaruan atau

\footnotetext{
27 Muhammad Abid al-Jabiri, Post-Tradisionalisme..., 186

28 Muhammad Abid al-Jabiri, Formasi Nalar Arab: Kritik. Tradisi Menuju Pembebasan dan Pluralisme Wacana Interreligius (Yogyakarta: Ircisod, 2003), 26.

${ }_{29}$ Muhammad Abid al-Jabiri, Kritik Kontemporer atas Filsafat Arab-Islam (Yogayakrta: Penerbit Islamika, 2003), 14.

30 Muhammad Abid al-Jabiri, Post-Tradisionalisme..., 186.
} 
pengembangan dengan mengadopsi caracara baru, baik itu bersumber dari tradisi Timur maupun tradisi Barat (orang lain), tanpa meninggalkan cara-cara lama yang berguna dan menunjang pembaruan sebagai titik-simpul kesinambungan. Abid al-Jabiri mengistilahkan kelompok eklektis (taufiqiyyun). ${ }^{31}$ Semangat dan pola pikir kelompok ini pada dasarnya serupa dengan pola pikir pesantren dalam mengupayakan sebuah pembaruan atau pengembangan.

Pesantren dengan berpijak pada kaidah "al-mubafadzatu 'ala qadim al-shalib, wa al-abdzu bi al-jadid al-ashlab" sebenarnya menempati posisi eklektis; tidak konservatif dalam menanggapi kejayaan masa lalu, dan juga tidak menolak sepenuhnya terhadap konsep-konsep kemodernan yang lebih baik. Kedua kesadaran ini disatukan menjadi kesadaran yang bulat dalam mengupayakan pembaruan. Hal ini penting dilakukan ketika melihat perkembangan yang begitu pesat belakangan ini, baik itu kondisi internal maupun eksternal.

Seperti apa perkembangan internal dan eksternal pesantren belakangan ini? Sudah terjadi sejak lama perkembangan pesantren, dari tipologi salaf (tradisional) ke tipologi khalaf (modern). Terlepas dari pencapaian dari peralihan tersebut, perkembangan dari salaf ke pengadopsian sistem pengajaran umum (halaf) tentunya berpengaruh pada kecerdasan kognitif santri.

31 Muhammad Abid al-Jabiri, Post-Tradisionalisme..., 186.
Yang sebelumnya masih sangat kental dengan metode bandongan, belakangan sudah mulai familiar dengan sistem klasikal. Begitupula muatannya, yang sebelumnya masih kental dengan suasana klasik kitab kuning, belakangan mulai terbuka pada kitab-kitab kontemporer dan bacaan-bacaan buku, serta pelajaran umum lainnya; seperti sosiologi, antropologi, sejarah dan lain sejenisnya. Barangkali beberapa puluh tahun yang lalu, sulit ditemukan ilmuan-ilmuan yang pandai dan akrab dengan ilmu-ilmu aktual-kontemporer, akan tetapi perkembangan hari ini, banyak sekali jebolan-jebolan pesantren yang menjadi ahli pada ilmu-ilmu kontemporer tersebut. Demikian pula fasilitas-fasilitas belakangan, akses bacaan yang tidak sulit, karena pesantren telah membangun dan mengembangkan perpustakaan santri. Begitu juga diskusi-diskusi aktual mengenai problem terkini yang kerap dilakukan oleh santri. Hal ini menuntut pengembangan metode pembelajaran dan kajian kitab-kitab kuning. Hal yang sama juga terjadi di luar kompleks pesantren. Alasan ini barangtentu cukup manjadi dasar pesantren dalam melakukan pengembangan tradisi.

Kembali pada pertanyaan di atas, bagaimana mengembangkan metode bandongan tanpa meninggalkan tradisi dan menutup rapat konsep kemodernan. Pada bagian ini, penulis akan tetap mengadopsi Paulo Friere dalam mengembangkan metode 
bandongan. Kegelisahan Friere pada pendidikan gaya bank yang menindas menghasilkan sebuah penawaran metodologi yang relatif baru di dalam sebuah sistem pendidikan. Tawaran baru dari Friere adalah pendidikan dialogika. Pendidikan dialogika atau pendidikan sejati-dalam hal ini terbatas pada cara pengajarannya-akan terwujud dalam situasi komunikatif yang menuntut adanya praktek dialogis. Bagi pendidikan gaya dialogis, isi pelajaran dalam pendidikan bukan sebuah hadiah atau paksaaan, potongan-potongan informasi dalam diri pendidik yang statis, dan final, malainkan berupa penyajian kembali bersama murid tentang hal-hal yang ingin diketahui lebih banyak. $^{32}$ Sehingga pendidikan, misalnya pengkajian kitab-kitab kuning di pesantren, tidak dilaksanakan oleh kiai kepada santri secara monologis, teachercentred, dan top-down. Akan tetapi dilakukan secara bersama oleh kiai sekaligus santri.

Pendidikan dialogika menolak pendidikan gaya bank secara menyeluruh. Pendidikan dialogika menghendaki perubahan pendidikan yang hanya menjadi sebagai media tabung yang menuntut daya ingat. Hal ini paralel dengan dengan taksnomi Bloom, gaya pendidikan sangat sulit untuk melangkah ke tahap kognitif selanjutnya, yakni dari mengingat (remembering) yang selalu terkait dengan

32 Paulo Freire, Pendidikan Kaum Tertindas..., 84-85. hafalan ke tahap kedua, memahami (understanding). Tentunya di dalam tahap proses perkembangan kognitif ini terdapat sebuah kesadaran akan apa yang sedang dipelajari dan dihadapi. Jika Friere mengatakan bahwa pendidikan gaya bank adalah bentuk halus sistem pendidikan yang menindas, pendidikan dialogika adalah sistem pendidikan yang berusaha membebaskan. ${ }^{33}$

Demikian pula dalam metode bandongan yang dipakai dalam kajian kitab kuning di pesantren. Metode bandongan klasik tidak akan mampu meningkatkan daya kognitif santri karena masih kental dengan suasana monologis yang menekankan daya ingatan semata. Akan tetapi metode bandongan yang sudah dikembangkan akan mampu menghadirkan suasana dialogis yang dapat meningkatkan daya kognitif santri kepada tahap perkembangan kognitif memahami (understanding).

\section{E. PERKEMBANGAN METOdE BANDONGAN DI PESANTREN ATTARBIYAH}

Hal yang sama terjadi di dalam Pesantren Attarbiyah. Seperti penjelasan gambaran pokok pesantren ini di atas, metode bandongan merupakan metode yang digunakan oleh pengasuh untuk mengkaji kitab kuning. Tidak terdapat perbedaan yang besar dengan pesantren lainnya dalam

\footnotetext{
${ }^{33}$ Paulo Freire, Pendidikan Kaum Tertindas..., 61.
} 
melakukan kajian kitab kuning dengan menggunakan metode bandongan. Dalam penjalasan lainnya, tidak ada garansi terhadap santri untuk dapat memahami apa yang telah dikaji di dalam kitab kuning. Dalam hal ini kiai tetap menjadi aktor yang mendominasi pembelajaran. Artinya, program kajian kitab kuning berjalan dengan suasana monolog, teacher-centred, dan top-down.

Akan tetapi keadaan telah berkembang semenjak kembalinya Kiai Wazim (putera Kiai Huda) dari pondok tempat beliau menyantri. Perkembangan yang sangat menonjol dari inisasi Kiai Wazim adalah pengembangan metode bandongan yang disebut olehnya dengan sebutan sawir. Metode ini pertama kali digunakan di Pesantren Attarbiyah untuk mengkaji ilmu nahwu. Di dalam metode sawir, langkah pertama tidak jauh berbeda dengan metode bandongan. Hal ini dilakukan dengan cara kiai membaca, menerjemahkan, dan menjelaskan suatu pembahasan di dalam kitab kuning. Sedangkan santri menyimak, mencatat, dan mengingatnya tentang suatu pembahasan di dalam kitab yang sedang dipelajarinya. Setelah seminggu kajian itu berlangsung, pada minggu atau pertemuan berikutnya metode ini dilaksanakan menjadi dua sesi dengan durasi waktu yang lebih lama dibanding seminggu sebelumnya. Pada minggu kedua dan seterusnya, sesi pertama kiai melanjutkan pembacaan, penerjemahan dan penjelasan, dan santri menyimak, mencatat dan mengingatnya. Sesi pertama ini tidak ada perbedaan yang lebih dengan metode bandongan.

Namun demikian, pada sesi kedua santri mengambil alih menjadi aktor yang aktif di dalam sesi ini. Semua santri dibagi menjadi beberapa kelompok. Masing-masing kelompok terdiri dari lima orang. Satu kelompok menjadi narasumber pada satu pertemuan, dan bergantian dengan kelompok lainnya pada pertemuan berikutnya. Di dalam satu kelompok, masing-masing individu mendapat bagian untuk membaca, menerjemahkan dan menjelaskan ulang dari materi atau pembahasan yang telah dikaji pada pertemuan pertama, begitu pula kelompok berikutnya bertugas untuk menjadi narasumber tentang materi atau pembahasan berikutnya. Di dalam sesi ini terdapat diskusi, adu argument, dan membedah atau membuat satu contoh kasus untuk dibahas bersama. Hal ini dalam sebuah kegiatan akademik disebut dengan sitilah panel season.

Kondisi di atas menjadi tugas utama di dalam tulisan ini untuk dianalisis dengan pendekatan yang telah diajukan di atas. Analisis ini akan memberikan gambaran keberhasilan dari pembaruan metode kajian kitab kuning, serta kelebihan dan kekurangannya. Metode sawir atau panel season merupakan satu langkah pembaruan yang harus diapresiasi sebagai pengembangan metodologi di dalam tradisi 
pesantren yang dikonstrksi berdasarkan metodologi ushul-fiqh; "al-mubafadzatu 'ala qadim al-shalih, wa al-abdzu bi al-jadid alashlab". Dalam kata lain, metode bandongan tidak ditinggalkan secara keseluruhan karena tidak ada persoalan lain di dalamnya. Dalam artian hal itu merupakan bagian yang disebut al-qadim al-shaleh. Akan tetapi persoalannya di dalam metode bandongan tidak ada garansi atau tolok-ukur yang dapat digunakan untuk menunjukkan seberapa besar pemahaman santri terhadap penjelasan kiai tentang suatu kitab yang dipelajarinya. Selain metode ini relevan dan kontemporer bagi awal mula pertumbuhan Pesantren Attarbiyah (mu'shiran li-nafsibi), metode ini juga kontemporer bagi kondisi pengembangannya (mu'ashiran lana) karena sistem di dalamnya telah diperbaharui (upgrade) dengan pengadopsian cara-cara baru yang lebih baik dan bermanfaat (al-jadid alashlab), khususnya bagi tradisi pesantren yang sangat vertikal antara santri dan kiai. Artinya, pembaharuan itu tidak lain merupakan hasil dari upaya renovatif (mutajaddid) dengan cara meng-up-grade sikap dan pendirian dengan mengharmonisasikan tradisi dan kemodernan. ${ }^{34}$

Perkembangan ini juga berdampak secara positif kepada pengembangan dan peningkatan kognitif santri. Metode bandongan yang sebelumnya tidak

34 Muhammad Abid al-Jabiri, Formasi Nalar Arab..., 18; Muhammad Abid al-Jabiri, Kritik Kontemporer..., 2. memberikan garansi terhadap pemahan santri karena sistemnya yang monolog, dalam kata lain santri masih mengendap dalam tahap kofnitif memahami (remembering), pada tahap pengembangannya (sawir atau panel season) kognitif santri berkembang dan meningkat pada level pemahaman (understanding). Pada saat yang sama, sawir atau panel season menjadi alat ukur untuk mengetahui dan menguji pemahaman santri.

Pada tahap ini, proses pengembangan atau pembaruan metode bandongan dapat dikatakan berhasil. Berhasil tidak hanya hasil konkrit meningkatnya level kognitif santri dan adanya pengadopsian cara-cara baru. Akan tetapi juga berhasil secara metodologis dalam melakukan pembaruan tradisi yang tidak memutus mata-rantai kesinambungan antara masa lalu dan masa kini. Hal ini dalam ungkapan yang lain dapat dikatakan tidak konservatif terhadap masa lalu seperti sikap kalangan tradisionalis (salafiyyun), dan tidak pula bersikap seperti kalangan modernis (badatsiyyun) yang langsung memutus tradisi dan menjadikan modernitas Barat sebagai acuan kemodernannya. Akan tetapi pesantren, khususnya Pesantren Attarbiyah, berada di tengah-tengah (wasathiyyun) dengan cara menyatukan keduanya dengan mengambil sisi-sisi yang lebih baik. Abid alJabiri mengistilahkan kalangan ini sebagai kalangan eklektis (taufiqiyyun). 
Namun demikian, pencapaian ini tidak berarti tidak menyisakan masalah yang menuntut semua pesantren untuk mengupayakan pemecahannya. Masalah tersebut adalah pemahaman apa atau siapakah yang diperoleh oleh santri dalam memahami kitab kuning yang dipalajarinya? Terdapat satu analisis-kritis yang akan penulis kemukakan untuk menjawab pertanyaan ini. Analisis tersebut mengemukakan bahwa hubungan vertikal antara kiai dan santri menggambarkan bahwa kiai merupakan puncak hierarki di dalam lingkungan pesantren. Kekuasaan kiai bersifat mutlak atas santri-santrinya. ${ }^{35}$ Ikatan vertikal ini menjadi salah satu akibat terhadap lahirnya sistem bandongan yang monolog, top-down, dan teacher-centred di atas. Sistem yang monolog ini juga memberikan dampak lain, yaitu hilangnya kebebasan santri dalam berpikir kritis, berbeda pendapat dan pandangan dengan kiai. Sehingga apa yang dipahami kiai mengenai kitab yang dipalajari atau tentang Islam menjadi apa yang akan dipahami dan pegang erat oleh santri, baik itu tentang kandungan kitab kuning, maupun tentang ajaran-ajaran Islam. ${ }^{36}$

Penulis tidak akan menyalahkan analisis di atas. Akan tetapi penulis juga tidak akan membenarkannya. Penulis hanya

35 Ahmad Syafii Maarif, Islam dan Pancasila sebagai Dasar Negara. Studi tentang Perdebatan dalam Konstituante (Jakarta: LP3ES, 2006), 58.

36 Ahmad Syafii Maarif, Islam dan Pancasila..., 58. akan menganalisis hasil analisis di atas dengan pendekatan kontemporer. Salah satu kritik kalangan post-struktralis adalah hadirnya kembali metafisika kehadiran melalui sebuah tuturan, bunyi, atau phone (hal ini yang disebut fonosentrisme yang dikritik J. Derrida). Metafisika kehadiran atau istilahnya yang lebih keren biasa disebut logosentrisme adalah sistem metafisik yang mengandaikan adanya logos atau kebenaran transendental di balik segala yang tampak. Dalam kata lain, kehadiran logos dapat ditampailkan melalui hadirnya pengarang yang memiliki otoritas penuh terhadap makna yang ingin disampaikannya. ${ }^{37}$

Untuk lebih mudah memahaminya dan agar segera menemukan konteksnya dalam pembahasan ini, penulis akan segera menjelaskan fonosentrisme yang menjadi salah satu arena bagi proses pembuatan makna atau pemahaman. Tuturan atau bunyi (phone) sudah pasti dapat menghadirkan penutur sebagai subjek dalam kegiatan berbahasa. $^{38}$ Sehingga apa yang dipahami oleh pendengar harus sesuai dengan apa yang hendak disampaikan oleh penutur. Karena makna hadir kepada pendengar melalaui mekanisme kehati-hatian yang selalu mencocokkan antara maksud atau kehendak yang hendak disampaikan (intention) dan tuturan (utterance). ${ }^{39}$ Dengan

\footnotetext{
37 Muhammad al-Fayyadl, Derrida (Yogyakarta: LKIS, 2005), 16.

${ }^{38}$ Muhammad al-Fayyadl, Derrida, 43.

39 Christopher Norris, Membongkar Teori Dekonstruksi Jecques Derrida (Yogyakarta: Ar-Ruz Media, 2009), 57.
} 
Nidhomul Haq, Vol 4 No 1 Tahun 2019

demikian, fonosentrisme merupakan keterpusatan bahasa ke dalam bunyi, dan karananya fonosentrisme adalah bentuk lain dari logosentrisme atau metafisika kehadiran yang mengikat antara penutur, suara, dan makna menjadi satu. ${ }^{40}$

Begitupula halnya dengan kondisi di dalam metode bandongan, kiai sebagai penutur yang menggunakan suaranya sebagai medium penyampai makna atau pemahaman kepada santri menjadi satu-kesatuan yang diterima oleh santri secara utuh. Sehingga sepanjang santri mengingat atau membaca kembali apa yang telah dipelajarinya, kiai sebagai pembentuk makna pertama yang diterima oleh santri akan terus hadir. Santri sebagai pendengar tidak bisa lepas dari makna awal yang disampaikan oleh kiai, karena makna, suara, dan kiai menjadi satu di dalam ingatan santri. Oleh karenanya, pengembangan metode bandongan yang disebut sawir atau panel season tetap menyisakan problem atau kekurangan yang terus menuntut pengembanganpegembangan tanpa henti.

\section{F. KESIMPULAN}

Pengembangan sebuah tradisi selamanya tidak dapat diputuskan dengan masa lalu. Pesantren dalam kasus ini, seberapapun jauh perkembangannya tidak akan dapat meninggalkan tradisi pesantren yang khas. Dalam kata lain, pesantren tidak

${ }^{40}$ Muhammad al-Fayyadl, Derrida..., 45-47. akan meninggalkan cara-cara lama yang baik, dan menjauhi cara-cara baru yang lebih baik. Hal itu terhadi disebabkan karena logika dasarnya yang dipegang sebagai metodologi berpikir adalah kaidah ushul-figh "almuhafadratu 'ala qadim al-shalih, wa al-abdæu bi al-jadid al-ashlah". Logika ini sesuai dengan kerangkan berpikirnya Abid al-Jabiri di dalam membangkitkan tradisi Arab-Islam di satu sisi dan kebangkitas Islam di sisi lain.

Bagi Abid al-Jabiri, satu-satunya kelompok yang berhasil mencapai kemodernan adalah kelompok yang tidak menjadikan kejayaan masa lalu sebagai acuan kemodernan dan tidak pula menjadi modernitas Barat yang tidak memiliki akar kesinambungan dengan masa lalu sebagai acuan kemodernan. Akan tetapi mengkolaborasikan keduanya menjadi satu bentuk kebangkitan. Dengan ini, masa lalu menjadi titik keberangkatan kebangkitan dan masa kini yang kontemporer dengan kekiniannya menjadi penopang kemodernan untuk melakukan lompatan-lompatan ke masa depan. Kelompok ini yang disebut dengan istilah eklektis (taufiqiyyun).

Dengan melihat kesesuaian kerangka berpikirnya kelompok eklektis dengan logika ushul-fiqh di atas, pesantren adalah kelompok nyata dari keduanya. Pesantren Attarbiyah sebagai objek kajian dalam tulisan ini berhasil melakukan sebuah upaya pengembangan tradisi, yaitu pengembangan metode bandongan. Secara metodologis, 
Pesantren Attarbiyah berhasil melakukan pembaruan tradisi disebabkan karena tidak memutus mata-rantai kesinambungan antara masa lalu dan masa kini (pengadopsian caracara baru yang lebih baik). Di sisi lain, dapat disebut berhasil karena hasil konkrit meningkatnya level kognitif santri dari level mengingat (remembering) menuju ke level pemahaman (understanding).

Terakhir, tak ada gading yang tak retak. Tulisan ini merupakan hasil dari satu sudut pandang filosofis terhadap perkembangan pesantren yang sangat mungkin menghasilkan kesimpulan lain, berbeda, dan barangkali lebih akurat dan objektif jika dilakukan pengamatan ulang dengan menggunakan pendekatanpendekatan yang lain. Walaupun demikian, hasil analisis penulis terhadap objek kajian ini masih jauh dari kesempurnaan. Namun yang pasti ini adalah pendapat penulis yang sangat terbuka terhadap saran dan kritikan. Wa allahu a'lam.

\section{G. DAFTAR PUSTAKA}

A'isyah, Siti. "Membaca Al-Jabiri: Menggali Inspirasi dari Post-Tradisionalisme Islam." Jurnal Pusaka 2, no. 2, (Januari-Juni 2015).

Achidsti, Sayfa Aulia. "Strategi Penyebaran Tradisi Islam pada Masyarakat Jawa." Ibda': Jurnal Kebudayaan Islam 10, no. 2, (Juli-Desember, 2012).

Al-Fayyadl, Muhammad. Derrida.
Yogyakarta: LKIS, 2005.

Al-Jabiri, Muhammad Abid. Formasi Nalar Arab: Kritik Tradisi Menuju Pembebasan dan Pluralisme Wacana Interreligius. Yogyakarta: Ircisod, 2003.

Kritik. Kontemporer atas Filsafat Arab Islam. Yogayakrta: Penerbit Islamika, 2003.

Post-Tradisionalisme Islam.

Yogyakarta: LKIS, 2000.

Anwar, Ali. Pembaruan Pendidikan di Pesatren Lirboyo Kediri. Yogyakarta: Pustaka Pelajar, 2011.

Azra, Azyumardi. Jaringan Ulama Timur Tengah dan Kepulauan Nusantara Abad XVII \& XVIII; Akar Pembaruan Islam Indonesia. Jakarta: Kencana, 2005.

Bruinessen, Martin Van. Kitab Kuning, Pesantren, dan Tarekat. Yogyakarta: Gading Publishing, 2012.

Effendi, Djohan. Pembaruan Tanpa Membongkar Tradisi: Wacana Keagamaan diKalangan Generasi Muda NU Masa Kepemimpinan GUS DUR. Jakarta: Kompas, 2010.

Farchan, Hamdan dan Syarifuddin. Titik Tengkar Pesantren. Resolusi Konflik Masyarakat Pesantren. Yogyakarta: Pilar Media, 2005.

Fatmawati, Sri. "Perumusan Tujuan Pembelajaran dan Soal Kognitif Berorientasi pada Revisi Taksonomi Bloom dalam Pembelajaran Fisika." Edusain 1, no. 2 (Desember 2013).

Freire, Paulo. Pendidikan Kaum Tertindas. Jakarta: LP3ES, 2011.

Haidari, Amin, dkk,. Masa Depan Pesantren dalam Tantangan Modernitas dan 
Nidhomul Haq, Vol 4 No 1 Tahun 2019

Tantangan Kompleksitas Global. Jakarta: IRD Press, 2014.

Hariadi. Evolusi Pesantren: Studi Kepemimpinan

Kiai Berbasis Orientasi ESQ.

Yogyakarta: LKIS, 2015.

Kompri. Manajemen dan Kepemimpinan Pondok Pesantren. Jakarta: Kencana, 2018.

Maarif, Ahmad Syafii. Islam dan Pancasila sebagai Dasar Negara. Studi tentang Perdebatan dalam Konstituante. Jakarta: LP3ES, 2006.

Ma'arif, Syamsul, dkk. "Inklusifitas Pesantren Tebuireng: Menatap Globalisasi dengan Wajah Tradisionalisme." Jurnal Pembangunan Pendidikan: Fondasi dan Aplikasi 3, no. 1, (Juni, 2015).

Makin, Al. Anti-Kesempurnaan: Membaca, Melihat dan Bertutur tentang Islam. Yogyakarta: Pustaka Pelajar, 2002.

Norris, Christopher. Membongkar Teori Dekonstruksi Jecques Derrida. Yogyakarta: Ar-Ruz Media, 2009.

Mughits, Abdul. Kritik Nalar Figh Pesantren. Jakarta: Kencana, 2008.

Muslih, Muhammad. "Pemikiran Islam Kontemporer: Antara model Pemikiran dan Model Pembacaan." Jurnal Tsaqafah 8, no. 2, (Oktober 2012).

Nurhayati, Aisatun. "Literatur Keislaman dalam Konteks Pesantren." Pustakaloka 5, no. 1 (2013).

Qomar, Mujamil. Pesantren: Dari Transformasi Metodologi Menuju Demokratisasi Insitusi. Jakarta: Erlangga, 2009.

Ritzer, Geroge. Sosiologi Imu Pengetahuan Berparadigma Ganda. Yogyakarta: Pustaka Pelajar, 2014.
Rofi, Sofyan. Sejarah Pendidikan Islam di Indonesia. Yogyakarta: Deepublish, 2018.

Rouf, Abdul Mukti. "Metode Pembcaan Turats Arab-Islam: Perspektif Muhammad Abid al-Jabiri." Ulumuna XIV, no. 1, (Juni 2010).

Sanusi, Uci. "Transfer Ilmu di Pesantren: Kajian Mengenai Sanad Ilmu." Ta'lim: Jurnal Pendidikan Agama Islam 11, no. 1 (2013).

Suprihatiningsih. Perspektif Manajemen Pembelajaran Program Keterampilan. Yogyakarta: Deepublish, 2016.

Takdir, Mohammad. Modernisasi Kurikulum Pesantren: Konsep dan Metode Antroposentris. Yogyakarta: Ircisod, 2018.

Tan, Charlene. Islamic Education and Indoctrination; The Case in Indonesia. New York: Routledge, 2014.

Usman, Ali. Kiai Mengaji, Santri Ajungkan Jari: Refleksi Kritis atas Tradisi dan Pemikiran Pesantren. Yogyakarta: Pustaka Pesantren, 2012.

Yulianti. "Pengembangan Alat Evaluasi Hasil Belajar Pelajaran Mata Pelajaran Pendidikan Agama Islam Berbasis Taksonomi Bloom Dua Dimensi." Joies 1, no. 2, (Desember 2016).

Zuhri. Convergentive Design Kurikulum Pendidikan Pesantren (Konsepsi dan Aplikasinya). Yogyakarta: Deepublish, 2016. 